\title{
Analysis of the touristic potential of mountainous areas in Ivano-Frankivsk region to create the development conditions for recreation in the Carpathian region of Ukraine
}

Análise do potencial turístico de áreas montanhosas na região de IvanoFrankivsk para criar as condições de desenvolvimento para recreação na região dos Cárpatos da Ucrânia

Ivan Smadych[a] (D)

[a] Ivano-Frankivsk National Technical University of Oil and Gas, Institute of Architecture, Construction and Power Engineering, Ivano-Frankivsk, Ukraine

How to cite: Smadych, I. (2019). Analysis of the tourist potential of mountainous areas in Ivano-Frankivsk region to create the development conditions of recreation in the Carpathian region of Ukraine. urbe. Revista Brasileira de Gestão Urbana, 11, e20190011. https://doi.org/10.1590/2175-3369.011.e20190011

\section{Abstract}

At present, the development of tourism is a priority for the Carpathian region. However, the unwise construction and lack of a clear strategy for the development of recreational infrastructure has led to environmental problems in some mountain areas. An important component of diversity and the balanced development of the tourism industry is the possibility of fast analysis of the recreational potential availability and the future functions of the recreational facility. In this study, the formation of a common model of tourism potential on the example of several administrative districts was substantiated. The presented research algorithm includes: 1) conditional division of recreational resources for this region into natural-landscape, historical and artistic, socio-economic tourist resources with their internal classification; 2) spatial location of tourist resources; 3 ) creation of a species intensity scheme of tourist resources, which will become the basis for the creation of the urban development concept in these territories.

Keywords: Unoccupied tourist resources. Carpathian region of Ukraine. Natural-landscape tourist resources. Historical and artistic tourist resources. Socio-economic tourist resources.

\section{Resumo}

Atualmente, o desenvolvimento do turismo é uma direção prioritária para a região dos Cárpatos. No entanto, a construção imprudente e a falta de uma estratégia clara para o desenvolvimento de infraestruturas recreativas levaram a problemas ambientais em algumas áreas montanhosas. Um componente importante da diversidade e do desenvolvimento equilibrado da indústria do turismo é a possibilidade de análise rápida da disponibilidade do potencial recreativo e das futuras funções da instalação recreativa. Neste estudo, foi evidenciada a formação de um modelo comum de potencial turístico a partir do exemplo de vários distritos administrativos e é apresentado o algoritmo de pesquisa, que inclui: 1) divisão condicional dos recursos recreativos para esta região em paisagem natural, histórica e artística, e recursos turísticos socioeconômicos com sua classificação interna; 2) localização espacial dos 
recursos turísticos; 3) criação de um esquema de intensidade das espécies de recursos turísticos, que se tornará a base para a criação do conceito de desenvolvimento urbano desses territórios.

Palavras-chave: Recursos turísticos desocupados. Região dos Cárpatos da Ucrânia. Recursos turísticos de paisagem natural. Recursos turísticos históricos e artísticos. Recursos turísticos socioeconômicos.

\section{Introduction}

\section{Prerequisites}

The Carpathian region of Ukraine is a territory with unique natural-landscape conditions, architectural and artistic peculiarities known in Europe and in the world. However, the lack of workplaces, seasonal migration, as well as demographic problems of the inhabitants of this region led to the disappearance of some mountain settlements and the loss of unique objects of residential and sacred architecture that are listed in the UNESCO list of monuments (Pozniak, 2016; Pitiulych, 2015; Dovzhuk, 2005).

The development of tourism is a priority task of the Carpathian region in Ukraine. However, the chaotic organization of tourist infrastructure and the lack of a strategy for development and construction have led to environmental problems in certain areas of intensive development (Panchenko, 2000).

Therefore, the purpose of the study is to formulate an analysis of the tourism potential of individual settlements, which can be applied by small architectural studios or administrative authorities during the pre-project analysis or the creation of urban development schemes for individual territories. In our opinion, this study will be relevant for countries with a developing economy. This will justify the priority directions of the formation of tourist-oriented architecture and in the absence of a clear strategy for the development of the region in architecture, as well as to preserve the authentic handicrafts of local ethnographic groups living in these territories (Hutsuls, Boyki, Lemki) (Ky'fyak, 2003).

\section{Review of literature}

\section{Arrangement of the tourist potential in the Carpathian region of Ukraine}

Tourist-resource potential - a set of natural, historical and cultural and socio-economic conditions for the organization of tourism activity in a certain territory (Richins, 2016). The study identifies 3 main types of tourism resources: natural-landscape, historical-cultural and socio-economic. This division is the best way to assess the tourist resources of the Carpathian region of Ukraine, although depending on the research area, it can be modified (Gabrel, 2004).

\section{Research on the identification recreational resources}

Similar studies of the tourism potential of certain territories in their works were conducted by Maruya, K., Yamashita, S., \& Uchiyama, T (Maruya et al., 2015). Ionela, G., Constantin, B.M., \& Dogaru, L. (Ionela et al., 2015; Steinberg, 1996).

However, they investigated a separate aspect of preserving the work of local craftsmen. In our experiment, an attempt is made to assess the possibility of using the entire tourist potential to create different types of recreation. 


\section{Methods}

In order to solve the problems in the process of work, a method of comprehensive study of recreational potential of the region was used, which was carried out both on the territory of the research, and stationary. Data collection for analysis took place in the field on the territory of mountainous regions of Ivano-Frankivsk region during the period from 2013 to the present. The study was conducted using the following algorithm:

- Analysis of statistical reporting. At the first stage of work the analysis of statistical reporting of district and regional departments of statistics was carried out. Also, the source of this study was the development programs of individual administrative districts of the region (Dolyna, 2011; State Statistics Committee of Ukraine, 2011). On the basis of which the analysis of the development of tourist districts and the location of infrastructure objects was made.

- Analysis of cartographic materials. An analysis of thematic maps, tourist guides and routes on the territory of the study that allowed to identify the main areas of localization of the studied recreational resources;

- Conducting architectural and urban inventory. At this stage of research, an analysis of urban planning documentation and master plans of individual sites was carried out. The application of this method has allowed to determine the relevance of placing recreational objects developed zoning in settlements;

- Natural examination. Comparison of the results of cartographic analysis in the research area. In addition, this made it possible to compare data from cartographic sources with their actual impact on the development of tourism in these territories.

\section{Analysis and evaluation of the unused recreational resources in the Carpathian region of Ukraine}

\section{Natural-landscape tourist resources}

Natural-landscape tourist resources - natural conditions of climate, water, insolation, humidity level, planting and quantitative and qualitative composition of flora and fauna, possessing indicators for the formation of tourism activities. To study the untapped tourist potential, it is advisable to group climatic and therapeutic tourist resources into a climatic-therapeutic group, because their implementation in modern recreation is complex. Balneological tourism resources - natural medicinal substances contained in mineral waters, mud and have therapeutic effects on the human body. Landscape tourism resources a set of surface irregularities of the landscape, providing the organization with a variety of recreation and planning solutions of the object architecture in accordance with the special conditions of high visibility and insolation (ski holidays etc.). Tourist resources of flora and fauna - high level provided by a diversity of animals and plants that are rare species and protected by law.

Forest tourism resources -detailed diversity and high forest level of the territory. In Ukraine, forested area is $14.2 \%$, with their placement uneven, due to the peculiarities of natural conditions, relief and human economic activity. In the Carpathian region, forest recreational resources occupy $40.5 \%$ of the total territory. 


\section{Historical and cultural tourist resources}

Another group of tourist resources that form the potential of the territory of the Carpathian region make up historical and cultural tourist resources - historical events, objects and phenomena of material and spiritual culture that have arisen in the conditions of historical development and arise at present.

Historical and cultural monuments are remarkable archeological objects or a work of art that is part of the cultural heritage of the country or humanity.

The archaeological sites include the ancient settlements, the remains of ancient settlements, elements of infrastructure, monuments, images, objects, etc. Architectural and urban architectural monuments are highly artistic architectural works, built in past historical periods, planning, space and space division and construction techniques, civil, religious, military and industrial architecture, and complexes and elements of garden art. The artistic monuments and museum group of tourist resources include examples of monumental, decorative and applied, fine arts.

The event tourist resources - The least-studied group of tourist resources in Ukraine, which arose with the growing number of cultural events with a marked cultural, cognitive and entertainment function. These include competitions, festivals, fairs, rallies, concerts, holidays, etc.

Ethnographic tourist resources are a component of historical and cultural potential, which includes the material and spiritual culture of an ethnic group or the entire nation: traditions, ceremonies, holidays, folk crafts, national cuisine, traditional dwellings, clothes, dances, etc. The Carpathian region has the unique potential of ethnographic tourism resources, which should become the core of tourism development and determine the identity of the region in the global context of this industry.

Religious tourist resources - objects and complexes of sacred significance are places of constant religious forgiveness, visits to recreation centers and the formation of a religious center within a separate region, state, and the world.

Religious tourist resources include churches, monasteries, places of burial of the saints, icons, and others like that.

\section{Socio-economic tourist resources}

Socio-economic tourist resources are a set of enterprises, institutions of objects and organizations of tangible and intangible assets and labor resources that provide the operation of these enterprises. These enterprises, institutions and organizations directly or indirectly participate in the tourism process, although by sectoral division do not relate to tourism (Figure 1).

Tourist resources of conditions of the object location - conditions of placement of the territory of tourist complexes in the structure of transport highways of regional, state and international importance. Placing in the central part of Europe with less than $300 \mathrm{~km}$ of accessibility to the EU countries creates conditions for permanent external tourist flows. As of 2016 in Kosivsky district 65\% of highways are in need of major repairs, in Verkhovyna 44\%. The best indicators in Nadvirna district make up 15\%. This problem is the main reason for the low development of recreation southwestern mountainous regions of IvanoFrankivsk region. Transport tourist resources - objects of transport infrastructure, providing movement of tourists to accommodation, food and recreation. These include all levels of public transport, taxis, railways and airports. Information tourism resources - the network of mass media, help centers, tourist companies that provide, inform the population with the features of rest, service and prices in the objects of architecture in the region. Also, informational tourism resources include scientific, periodical, creative literature, newsreels, which highlight the peculiarities of the region. 


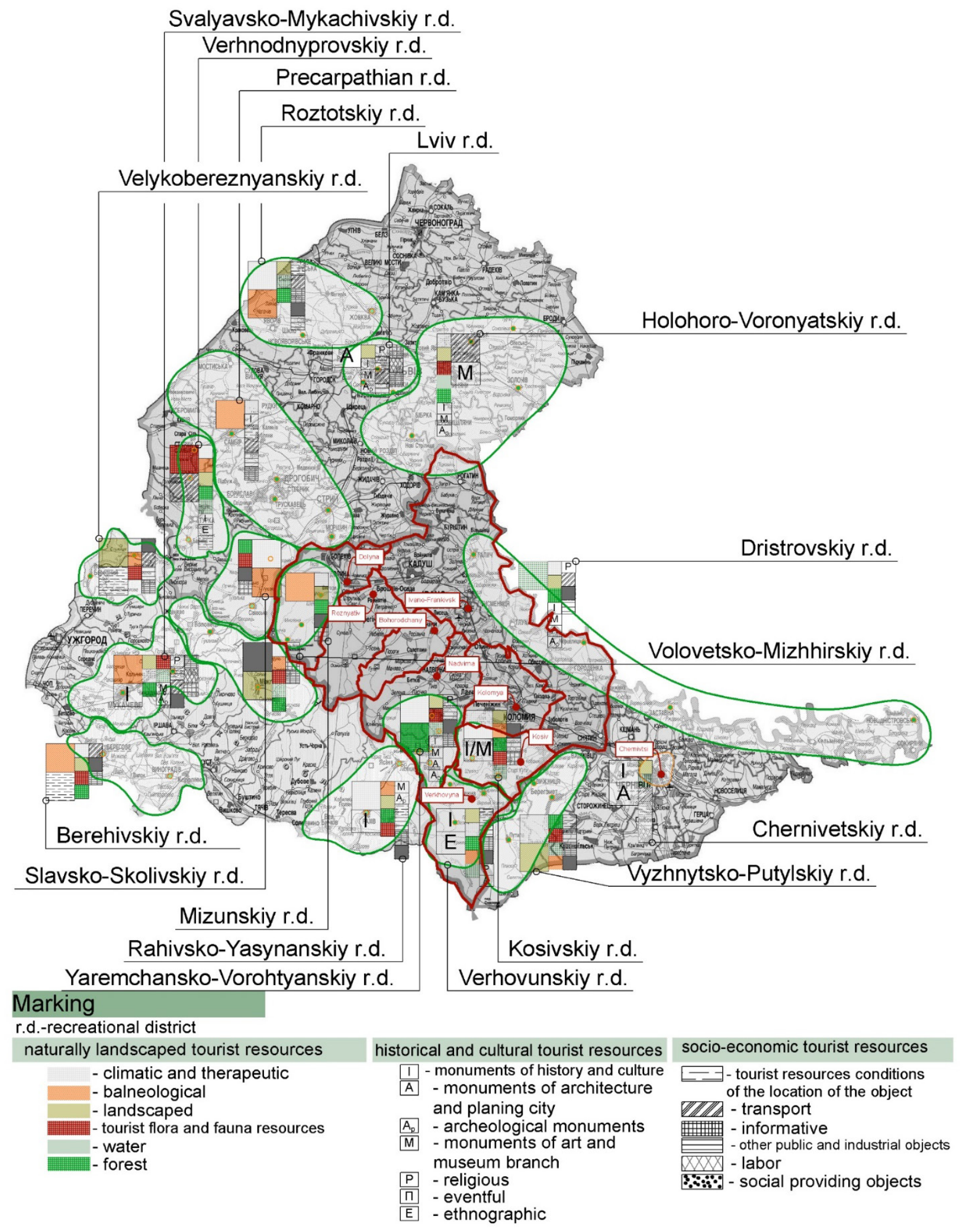

Figure 1 - Tourist zoning of the Carpathian region. The scheme was created during the field researches and author's information investigation.

The Carpathian region has the potential of labor tourism resources. More than 55\% of the population of the mountainous regions of the Ivano-Frankivsk region, at least once participating in labor migration, $28 \%$ annually work outside the region of residence (State Statistics Service of Ukraine, 2018). 
Tourist resources of the economic complex - there are objects of various branches of the economy, which ensure the functioning of the territory through its activities. The objects of the economic complex include power stations, enterprises of light, food industry, construction, agrarian enterprises. The tourist potential of the socially provided objects is the availability of existing objects of various industries, which are connected with the creation of conditions for providing life of residents and their comfortable stay in all territories. These include health, education, housing and communal services, communications, culture, consumer services.

\section{Spatial location of tourist resources in the mountainous regions of Ivano-Frankivsk region}

\section{Spatial location of natural-landscape tourist resources}

The Carpathian region of Ukraine has a high level of natural resources. With an area of 56.6 thousand $\mathrm{km} 2$ it accounts for a share of $12 \%$ of the tourist industry in Ukraine. However, there is a problem of ineffective use of them. The territory of the Carpathian region is represented by heterogeneous regions, both in the historical context and in terms of socio-economic development (Figure 2).

Zoning and distribution of tourist resources in the Carpathian region is based on recreational zoning. Placing of the enterprises of separate branches and formation of territorial connections, operating more than five decades, the territorial division of labor and recreational orientation of certain territories of the Carpathian region, is the basis of formation tourist zoning of its territory. Based on the data of the tourist specialization of the regions the selected regions of Ivano-Frankivsk region, scientific researches in this field and statistical reporting data, schemes of tourist resources placement in mountainous regions of Ivano-Frankivsk region were developed.

Climate-therapeutic tourist resources are a complex index of the microclimate: temperature, humidity, sunny days in summer and winter, the ecological situation, the state of drinking water, etc., which affect the well-being of a person in this environment.

On the basis of maps analysis of the ecological situation and the state of drinking water, the ecological situation (the index of pollution), climate maps and schemes of total pollution of the natural environment of Ukraine is determined that climatic and therapeutic tourist resources are located on $85 \%$ of the research area. 


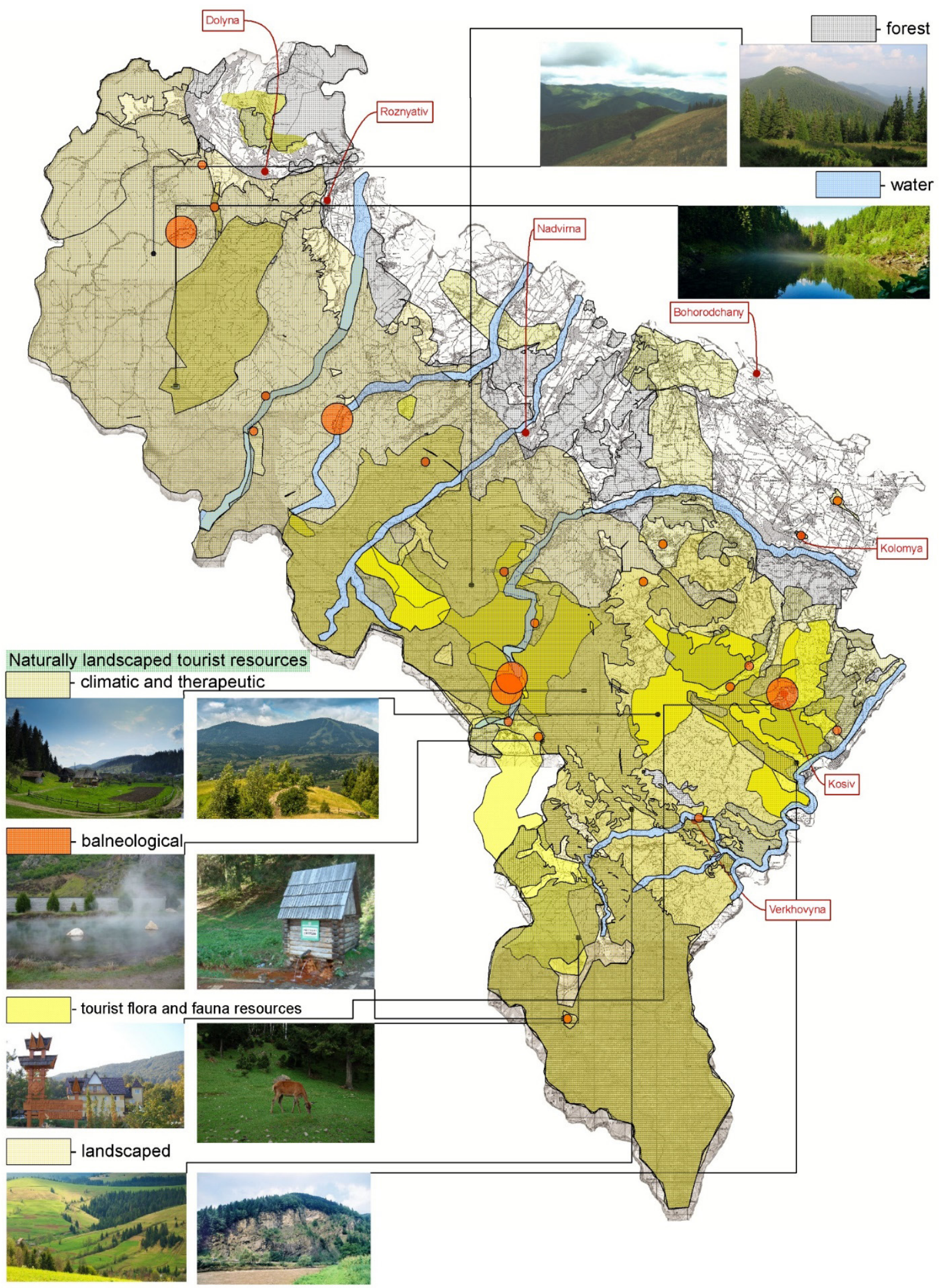

Figure 2 - Placement of natural-landscape recreational resources in the mountainous regions of Ivano-Frankivsk oblast. The scheme was created during the field researches and author's information investigation. 
The best indicators of the microclimate in the territory extending along the Chornohora ridge, within Kosiv, Verkhovyna, western parts of Kolomyia, Nadvirna, Dolyn and Rozhnyativsky districts. The ecosystem in Dolina and Nadvirna is violated by the activities of chemical and oil refineries. $73 \%$ of the research area has the potential of climate-therapeutic tourism resources (Smadych, 2015). More than 250 sources of balneological tourism resources have been discovered on the territory of the study. Only about $10 \%$ of the sources are scientific research. There is a potential for untapped spa tourism resources. On the territory of the region there are 4 institutions with a balneological profile of functioning. The potential of balneological tourism resources provides significant reserves for the development of recreation in the region.

Landscape tourism resources form the basis for the development of rural tourism and ski recreation. On the basis of analysis of the physical map of Ivano-Frankivsk region, the zones of influence of landscape tourism are defined: the mountainous part of the Carpathians within the boundary line of delimitation of which serve with. Big-Rozhen-River-Kosmach-Techeche of Kosivsky district, Bili Oslavy-Delyatin-Pnov of Nadvirna district, Babche-Krivets-Lvvetsya of Bogorodchansky district with Ilemnia-Pohar of Rozhnyativsky district, Staryi Mizun- Tserkovnia of Dolinsky district.The northern and northeastern ridges with a slope of less than 600 allow the creation of a network of mountain ski lifts on this territory. Their eastern border is Kosiv district, Zamulintsy - Kolomiya city - with Otinia of Kolomyia district, Gavrylivka - Hvizd of Nadvirnyansky district, Gorokholina-Gliboka of Bogorodchany district, the entire south-eastern part of the Rozhnyativ district, Trostyanets - Yakubov of Dolynsky district.

Analysis of cartographic materials of the reserve fund of the Ivano-Frankivsk region, features of the plant and animal world constitute a source base for analyzing the location of flora faunal tourism resources. 347 protected areas located in the southern and central parts of the mountain regions of IvanoFrankivsk region are located on the study territory. Their structure includes the natural reserve "Gorgany" (3712.89 hectares) located within the limits of the Dovbushan Gorgan in the southwestern part of Nadvirna district. The Carpathian National natural park (50495,0 hectares), the national natural park "Hutsulshchyna", the national natural park "Sinogara", Verkhovyna national natural park, 173 natural monuments and 168 nature reserves are also included. On the territory of the mountainous regions of Ivano-Frankivsk region there is a network of protected areas, which include 474 territories and objects which is $15.7 \%$ of the total area.

Tourist resources of this type have special conditions of use, because their localization coincides with the boundaries of protected areas. The natural object of the formation of water tourism resources are natural and artificial reservoirs (rivers, lakes, ponds, reservoirs). The study area has 8184 rivers with a total length of $11752 \mathrm{~km}$, as well as 130 natural and artificial reservoirs.

The width of the zone of this tourist resource is up to $150 \mathrm{~m}$ from the protected zone of the river in the mountainous part and up to $300 \mathrm{~m}$ in the foothills of the territory of Ivano-Frankivsk region.The main areas for the formation of recreation on the basis of water resources are the territory around the Cheremosh River (Barvinok village - the village of Ribne), Prut (Tatariv village - Kolomiya town), Limnitsa (Rozhnyatov), Bystrica Nadvirnianska (village Zelene - Tsutsulin), Bistrita Solotvinska (Solotvyn village - village Staryi Lyessets).

The problem of rubbing the local rivers is the selection of natural rocky rocks and the formation of quarries that change the ecosystem of the given year. Also, the discharges of small rivers of the Carpathian region are connected with the level of woodiness of the territory around them. Deforestation negatively affected $17 \%$ of small rivers of the studied area, which leads to their seasonal depreciation in the summer.

Forest tourism resources are located in more than $40 \%$ of the territory. Analysis of the forest area of the study showed the formation of 3 zones of forest tourism resources. The territory of intensive forest is the mountainous part of the region, which is limited to the following settlements: Bolechiv, Vygoda, Pereginsk, Bytkiv, Delyatin, Kosmach. Kryvorivnya, Stebnya. The territory of partial forest (less than 20\% of the total territory) is located from the north-east from the intensive forest zone with a conditional width of 20-60 km. It is defined by such settlements as: Velika Turia, Kropyvnyk, Zavii, Lysets, Lypivka, Otynia, Lanchyn, Velykyi Kliuchiv, Spas, Dzhuriv. Since 2000, massive illegal logging has led to negative 
consequences. The comparative analysis of the forest area using maps of different periods shows a decrease in the forest area in the period from 2000 to this time by $9.8 \%$ (Figure 3). Also, the decline in natural-landscape potential was triggered by the operation of the chemical and oil refining enterprises in the Dolina and Nadvirna regions of Ivano-Frankivsk region.

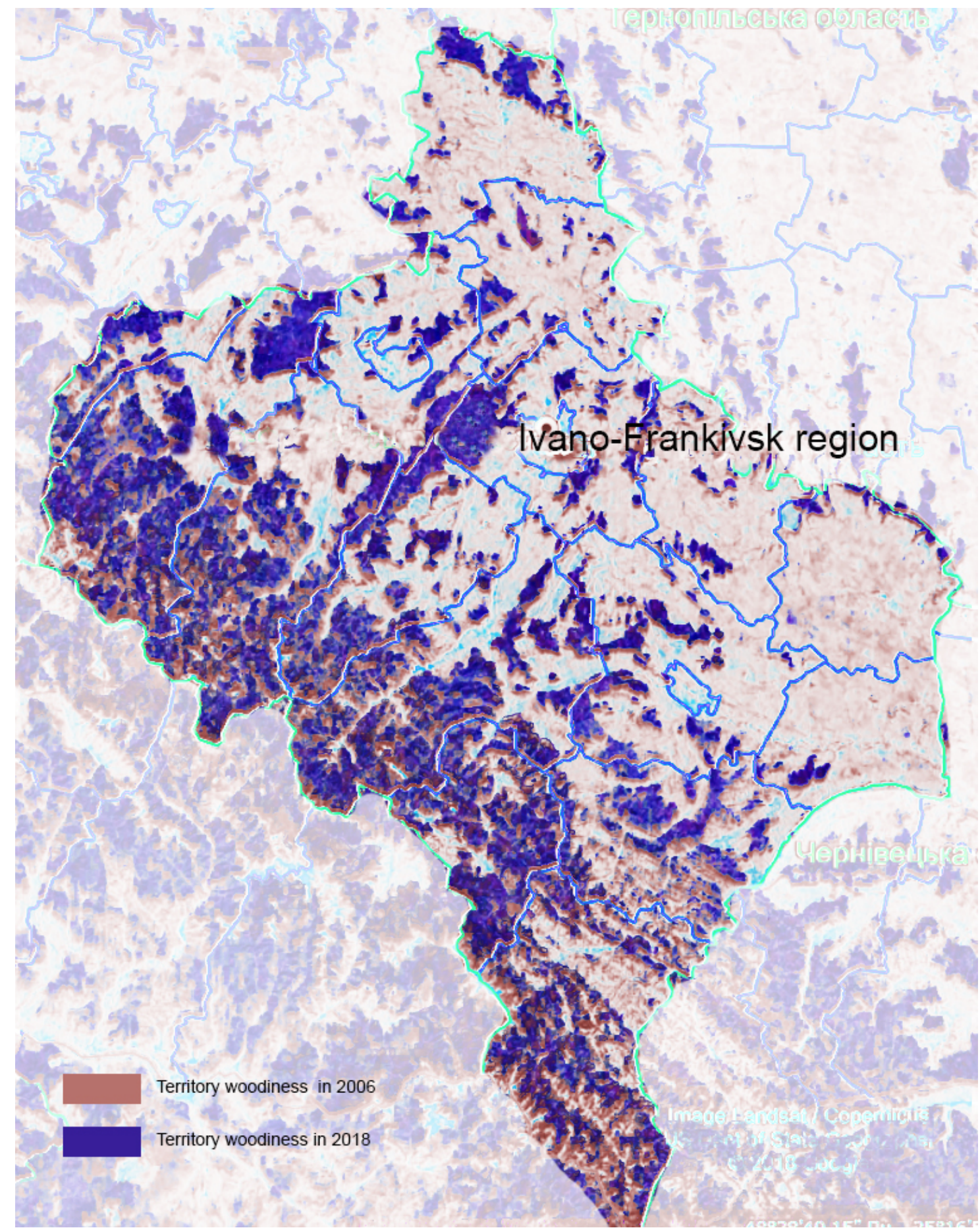

Figure 3 - Changes in the woodiness level on Ivano-Frankivsk territory during 2006-2018 periods. Comparative analysis made by the author with the GOOGLE Map usage (Google Maps, 2019). 


\section{Spatial location of historical and cultural tourist resources}

The analysis of historical and cultural monuments as a tourist resource has shown their location depending on the subspecies. Historic and cultural monuments are located throughout the study, which coincides with the territory of the ethnic centers of the region Hutsulshchyna, Boykivshchyna. Based on the researches of M. Kugutyak and L. M. Derzhipilsky, the zones of archaeological and recreational resources placement (Smadych, 2013), which cover the whole territory of the study, are outlined. However, the greatest intensity of recreational potential of this type is located within Kosiv and Verkhovyna districts. On the basis of the register of architectural monuments in Ivano-Frankivsk oblast a scheme of their location on the territory was developed, which shows the potential for the use of recreational resources of this type in the Kosiv, Verkhovyna and Nadvirna districts.

The event tourist resources have periodicity, which provides for special conditions for their development (recreation creation where event tourism resources will be an additional element of attraction, the conditions of mobility of architecture). An analysis of the electronic calendar of events in Ivano-Frankivsk oblast shows that the potential of this type of tourism is concentrated in district centers, partly in settlements and villages of Bogorodchansky, Verkhovyna and Kosivsky districts. The study area is the borderline between Latin and Byzantine culture, the crossroads of Western and Eastern Christianity, in which the "holy places" of Catholicism, Orthodoxy, Judaism, Protestantism, Armenian Church are preserved, acquaintance with which will be not only tourist-cognitive, but also primarily ecumenical-humanistic value. The basis of the spatial location of religious tourism resources was the study of Wang, J., \& Wang (Wang \& Wang, 2015).

By the number of architectural monuments and urban planning, the Ivano-Frankivsk region ranks third in Ukraine. Monasteries have always been the centers of tourism and regional studies (Wikipedia, 2017).

The most famous of them is the Dominican Monastery (1742-1762) - Bogorodchany district; Maniavskij Skete (1606 p.) - Maniava of Bogorodchany district; Goshiv Monastery (1570) - Dolyna district; Studynskyi Monastery (1938) - Yaremche city and others.

The most valuable monuments of sacred art are: Bogorodchany district - village Rosylnaya (Church of the Apostles Peter and Paul (the end of the nineteenth century and the church of Archangel Michael (1848); Dolynsky district - the village of Goshiv (the Church of the Holy Transfiguration (1842) (Figure 4).

The unique type of buildings in the studied region is the wooden churches of the ethnographic regions. Visual inspection of 123 architectural monuments shows that $85 \%$ of them are in poor condition or conditionally good condition, and need repair or restoration. Unfortunately, the lack of funding, and unreasonable interference in repair work without the involvement of experts in this area has led to the destruction of $5 \%$ of these objects (Figure 5 ).

Ethnographic potential of the region is formed due to a wide spectrum of samples of decorativeapplied, monumental, applied art, as well as folk traditions, folklore, cuisine, etc. The simple location of the ethnographic potential is formed in two directions: the location of objects and settlements whose inhabitants bear the authentic traditions and preserved samples of ethnography in the system of conducting government, the estate of folk artists, their workshops, etc. Such centers of districts and individual settlements, where the technologies of the manufacture of objects of arts and crafts are stored. For example, with. Kosmach, Sheshory, Yavoriv, Snidavka, Sokolivka of Kosiv district, Verkhovyna, Kryvopillya, Kryvorivnya, Bukovets of Verkhovyna district, Velikyi Kliuchiv, Rungury, Sloboda of Kolomyia district (Figure 6). 


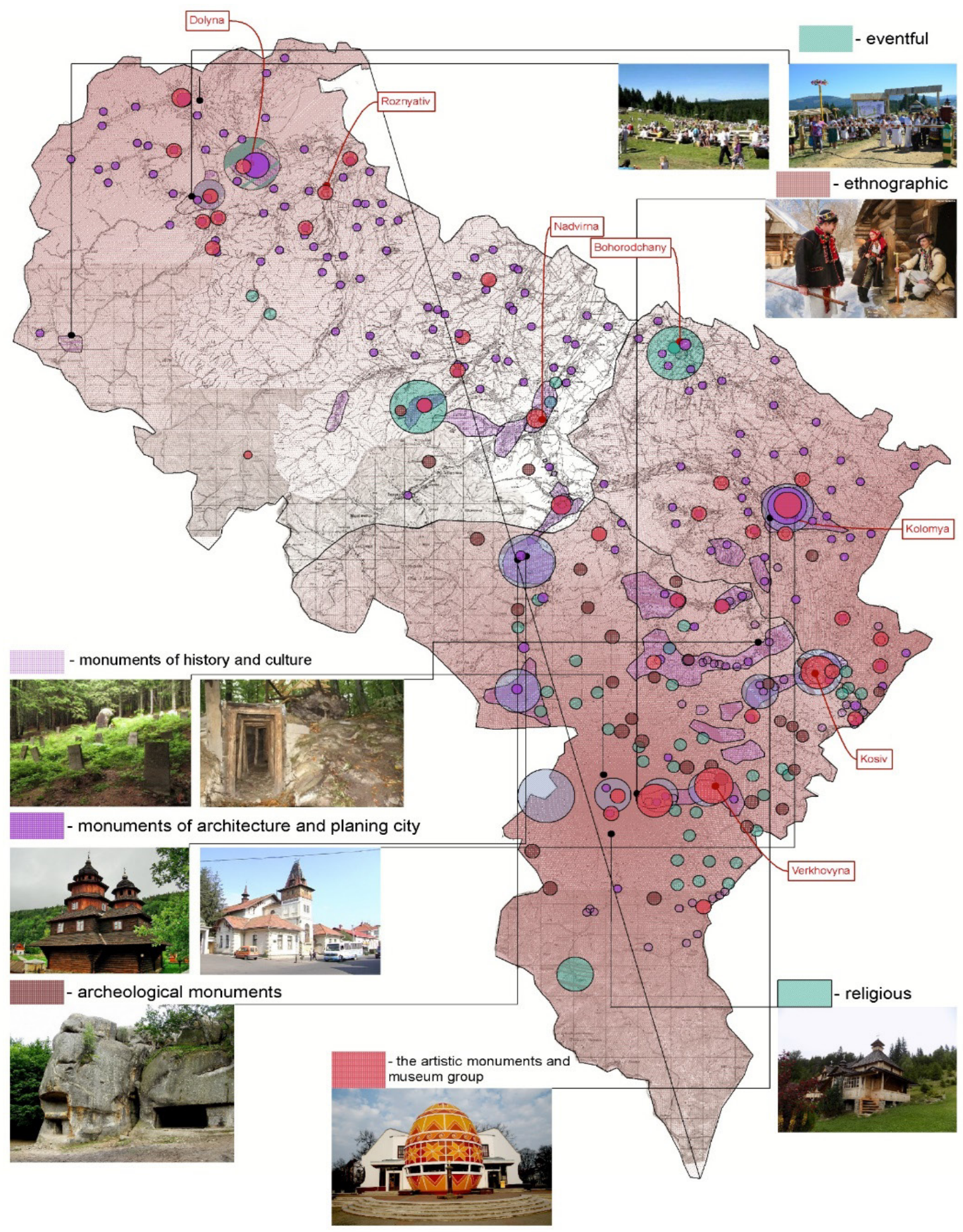

Figure 4 - Placement of historical and cultural recreational resources in the mountainous areas of IvanoFrankivsk region. The scheme was created during the field researches and author's information investigation. 


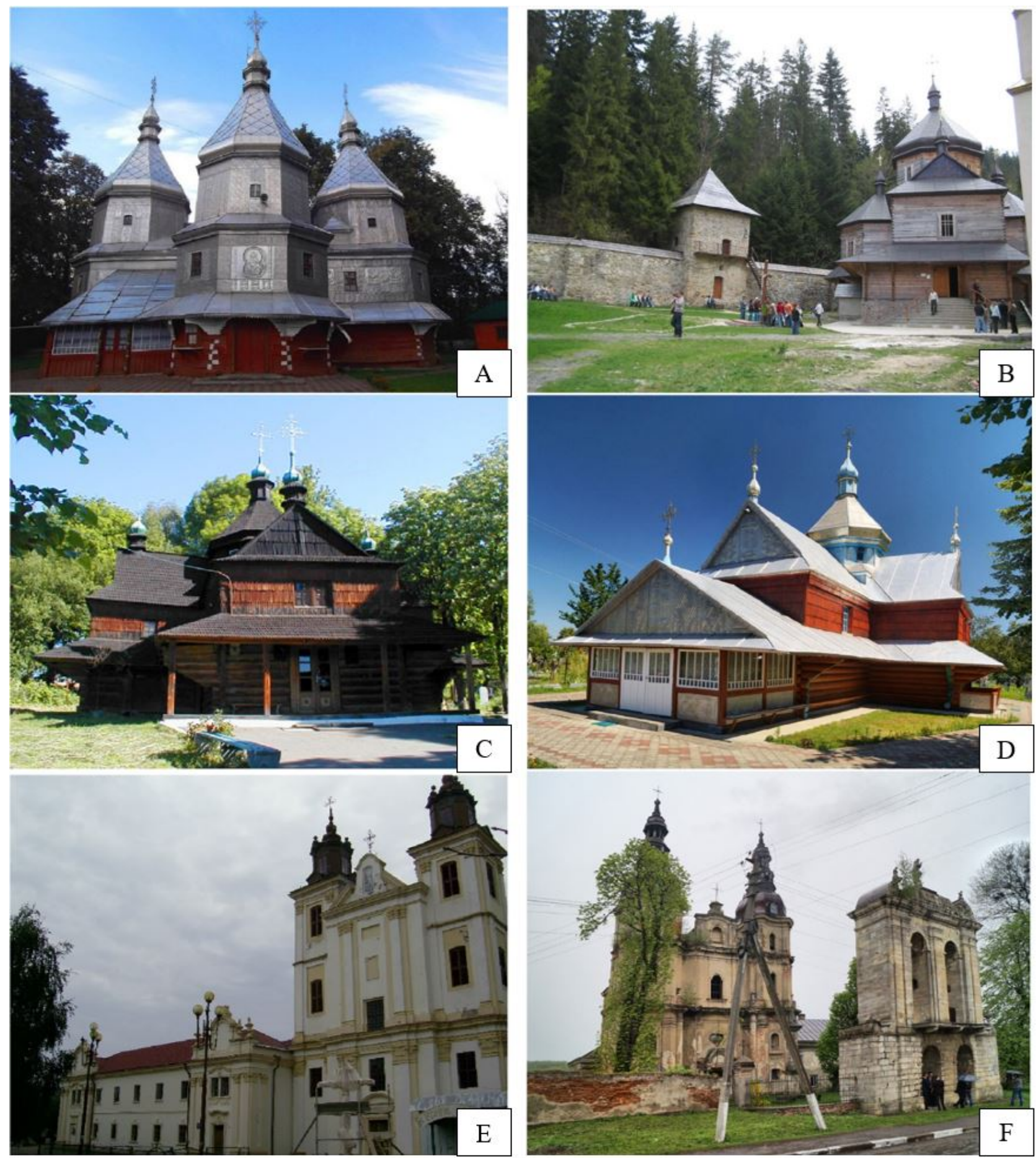

Figure 5 - Photo religious monuments of state importance in the territory of research. (A) The church of the Nativity of the Blessed Vingin, village Nyzhnii Verbizh, Kolomya district, UNESCO, 1808; (B) «Skyt Manyavskiy»» village Manyava, Bohorodchany district, XVII cen.; (C ) The church of the Virgin Mary Annunciation, in Kolomiia, 1587; (D) The church of the Virgin Mary Issumption, village Pistyn', Kosiv district 1868; (E) Roman Catholic church of Dominican brothers, Bohorodchany, 1691; (F). Bernardine Church, Gvizdets, Kolomyia district, $1723-1735$. Source: Photos are taken with reference to Decerkva (2019) and (IGotoWorld.com, 2019a). 


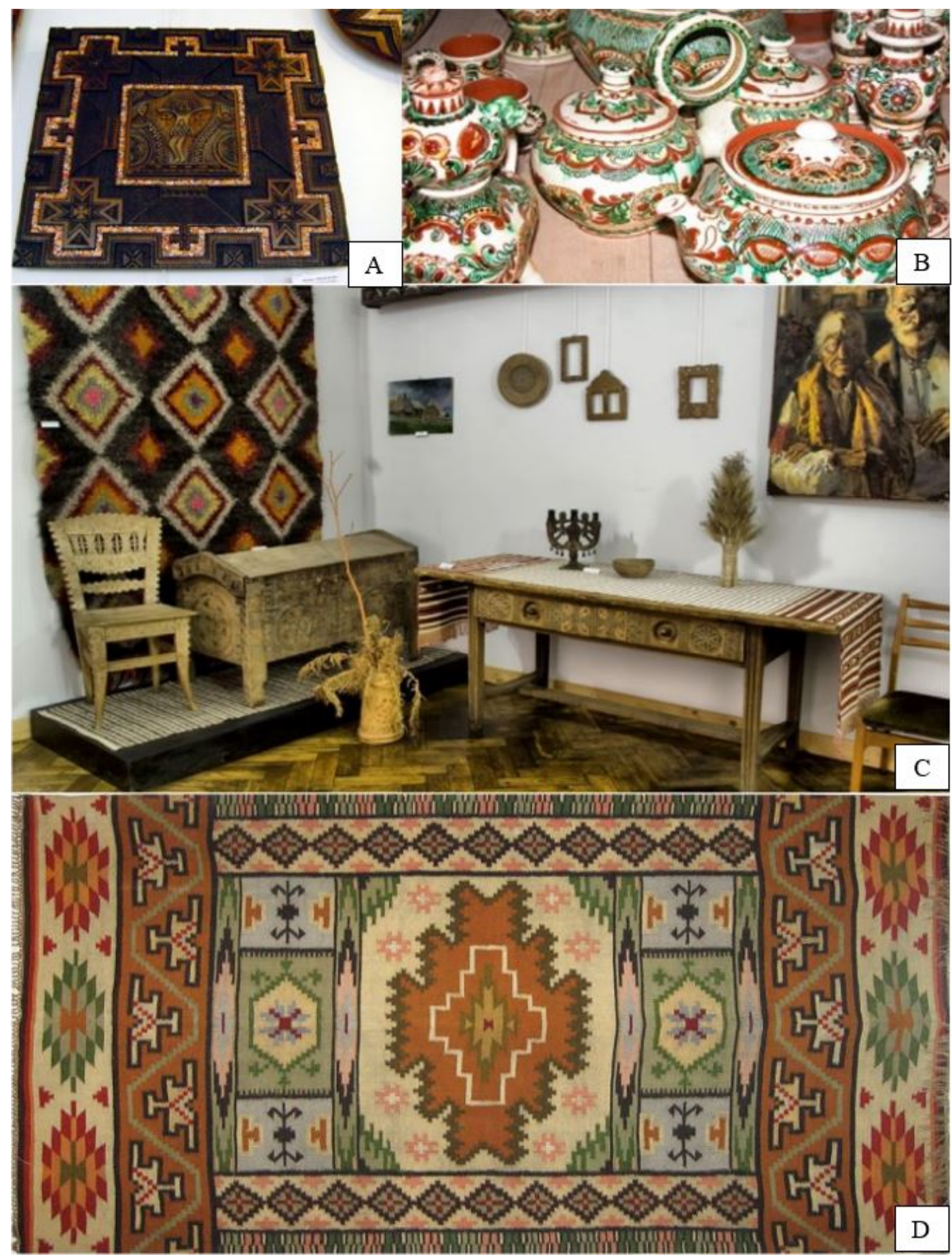

Figure 6 - Dec]orative and applied arts examples of the people from ethnographic districts in Ivano-Frankivsk region. (A) The carved icon, made by M. Strydaniuk; (B) Examples of pottery products in the Carpathian region;

(C) Authentic interior furniture in hutsyl's house (photo is from the National museum of folk ar of Hutsyl and Pokyttia regions, Kolomiia) (IGotoWorld.com, 2019b); (D) Woven "vereta" with authentic ornaments.

\section{Spatial location of socio-economic tourism resources}

The available tourist resources indicating the location of the object on the territory of the study are presented on the basis of analysis of the transport scheme of the region and the features of placement in the system of international and regional highways. The current scheme shows the potential of 
architectural objects in Nadvirna, Verkhovyna, Kosiv, Kolomyia Dolyna and Bohorodchany districts. Together with it, the scheme of transport tourist resources has been formed, which shows the possibilities of tourism development in Verkhovyna and southeastern part of Kosiv districts. The location of tourist information resources is based on the analysis of the information field of advertising of recreation facilities on Internet resources for renting real estate and spam-advertising when using the Internet.

The highest indicators are the territory of the Yaremche district, Nadvirna district (thanks to the operation of Bukovel TC), Kolomyia and Dolyna districts (Figure 7).

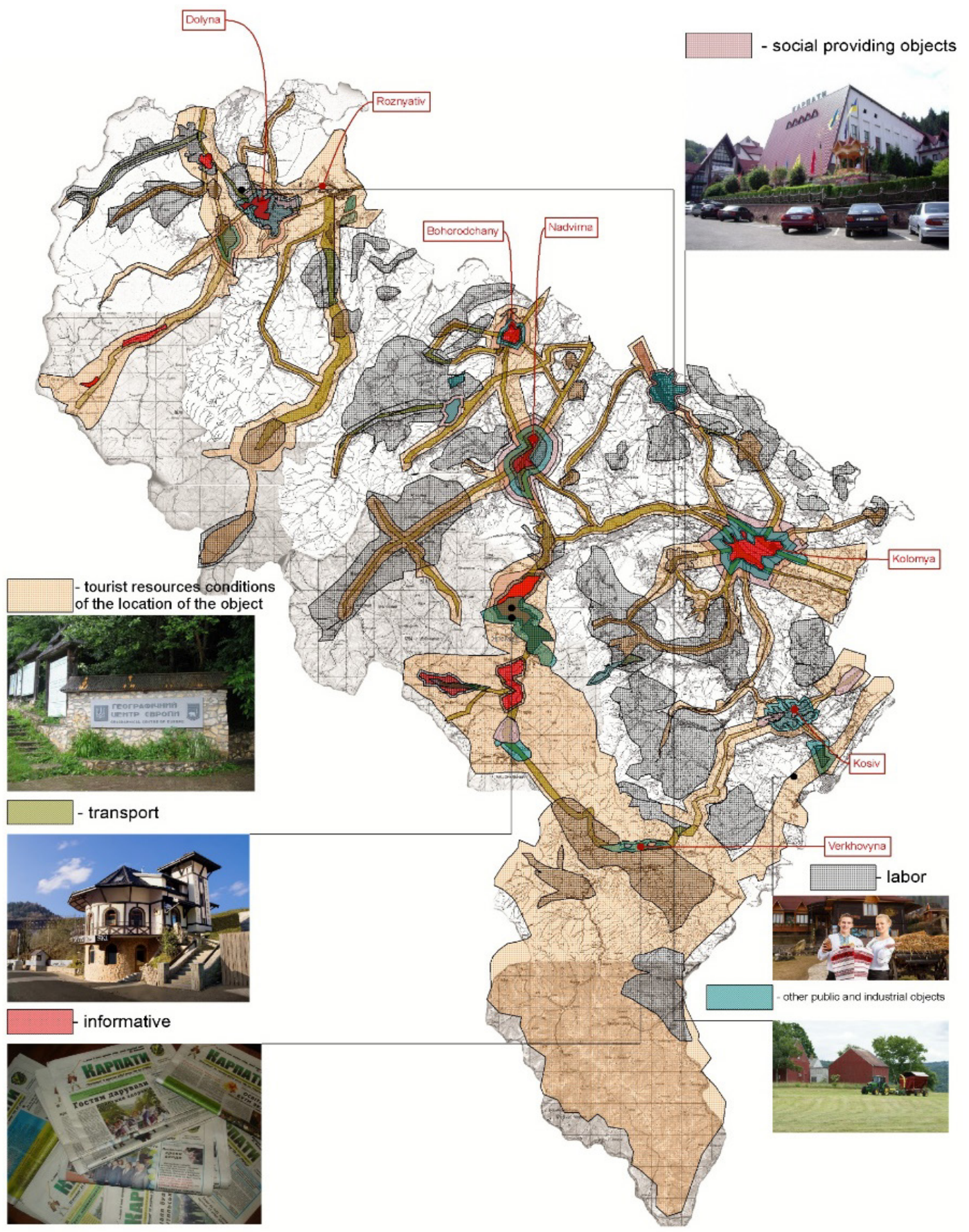

Figure 7 - Placement of socio-economic recreational resources in the mountainous regions of Ivano-Frankivsk region. The scheme was created during the field researches and author's information investigation. 
The spatial location of labor tourism resources is based on the statistical reporting of the unemployment rate for 2013-15. The highest unemployment rates are in Rozhnyatovsky and Verkhovyna districts of 8.5-9.2\%. The lowest Kolomyia district and the Yaremchaschyna city council area are $3.7-4.4 \%$. However, there is a problem of hidden unemployment and unemployment of the inhabitants of the mountainous part of the region where the figures can grow up to $50 \%$ (State Statistics Service of Ukraine, 2018).

Analysis of the location of the economic complex using the data of the regional department of statistics. They indicate the intensive placement of the industrial complex of the oil and gas industry in the district centers: the city of Nadvirna, the city of Dolyna and the Dolyna district. The agrarian complex operates in Kolomyia and partly in the Rozhnyativsky district. Woodworking specialty enterprises are located in Kosiv and Verkhovyna districts. These objects form the potential of the economic complex, which is a component of tourism. The potential of social services is Kolomyia district, Yaremcha, Bogorodchany, Nadvirna and some settlements of this district.

The analysis of the schemes of spatial dispersal of tourist resources in the mountainous regions of Ivano-Frankivsk region made it possible to substantiate the main integral features of the location, organization and development of the recreation area in the Carpathian region:

- the deciding place of relief in recreational zoning. In contrast to the foothills of the Carpathians, in the mountainous regions the intensity of tourism development is radial in the plains. In places of contact or intersection of high mountain ranges or mountains with a height of more than $50 \mathrm{~m}$ in relation to the nearest plain area serve as natural barriers to the development of tourism;

- insufficient development of the transport network. In the mountainous regions of Ivano-Frankivsk region, only $2 / 5$ of all highways have a connection without changing the category (district significance) with neighboring regions. At norm in Europe 8-10\%. The most acute problem is traced in Verkhovyna district.

With its unique ethnographic resources and location, it operates $15-20 \%$ of its potential due to transport accessibility and road quality. The most acute problem arose after the 2008 floods; Na important component of the uniqueness of the region is the diversity of tourist resources. The complexity of the location of tourist resources allows you to quickly reorganize the process of tourism at the local level and develop a strategy for the development of the region in the long run (Schmidt et al., 2016). The abundance and variety of tourist resources will allow thematic targeting of administrative areas and the creation of tourist units of the European model at the inter-district level.

\section{Assessment of the potential of untapped tourist resources of the region}

In the Carpathian region there is a tourism complex that represents a set of tourism objects and functiona links, as well as the use of natural and other resources. However, structural interconnections are formed in the 60-70-ies of the XX century. for today operate poorly. The main indicator of the efficiency of the recreational sector in any region is the annual number of tourists. It is a comparative analysis of the existing and maximum permissible number of tourists who annually visit the studied areas will allow obtaining results of the effectiveness of the functioning of these territories. The research was conducted on the basis of the recreational zoning scheme in the Carpathian region.

In the scheme of spatial dispersal of tourist resources, the maximum estimated number of visitors was introduced in the summer and winter seasons of 2017. However, the statistics obtained only show the proportion of tourists in the group of organized groups and tourists who register in hotels and cottages in institutions. The ratio of organized to spontaneous tourism is (Richins, 2016): organized tourism 40\%; spontaneous (wild) tourism - 60\% (Table 1). 
Table 1 - Maximum-acceptable indicators of tourist load in the mountainous regions of Ivano-Frankivsk region

\begin{tabular}{ccc}
\hline The name of the administrative district & $\begin{array}{c}\text { Number of recreation in the summer } \\
\mathbf{( 4 . 2 0 1 7 - 9 . 2 0 1 7 )}\end{array}$ & $\begin{array}{c}\text { Number of recreation in the winter } \\
\mathbf{( 1 1 . 2 0 1 7 - 0 3 . 2 0 1 8 )}\end{array}$ \\
\hline Nadvirnianskyi & 96400 & 149200 \\
Kosivskyi & 44100 & 13680 \\
Verhovynskyi & 10504 & 23569 \\
Dolynskyi & 12700 & 8040 \\
Kolomyiskyi & 17400 & 12465 \\
Rozhniativskyi & 9712 & 7641 \\
Bogorodchanskyi & 11476 & 13465 \\
\hline
\end{tabular}

The maximum allowable tourist load in the regions of Ivano-Frankivsk Oblast is $20.55 \%$ in summer and $30.75 \%$ in winter. The highest percentage of tourist load in the mountainous part of the Carpathians is observed in the Yaremche district-Vorokhta region, which is $74.6 \%$ in winter and $24 \%$ in summer (the reason for this is the operation on the above-mentioned territory of the tourist complex "Bukovel"). The percentage of visits in adjacent areas with adjacent resource potential is relatively similar.

This comparative analysis demonstrates the recreational load within the recreational areas, but does not show the effectiveness of the use of recreational potential. In order to obtain indicators for estimating the potential of unused recreational resources, a comparative analysis of the spatial location of recreational resources and the intensity of the recreational activities of the region should be conducted (Figure 8). 


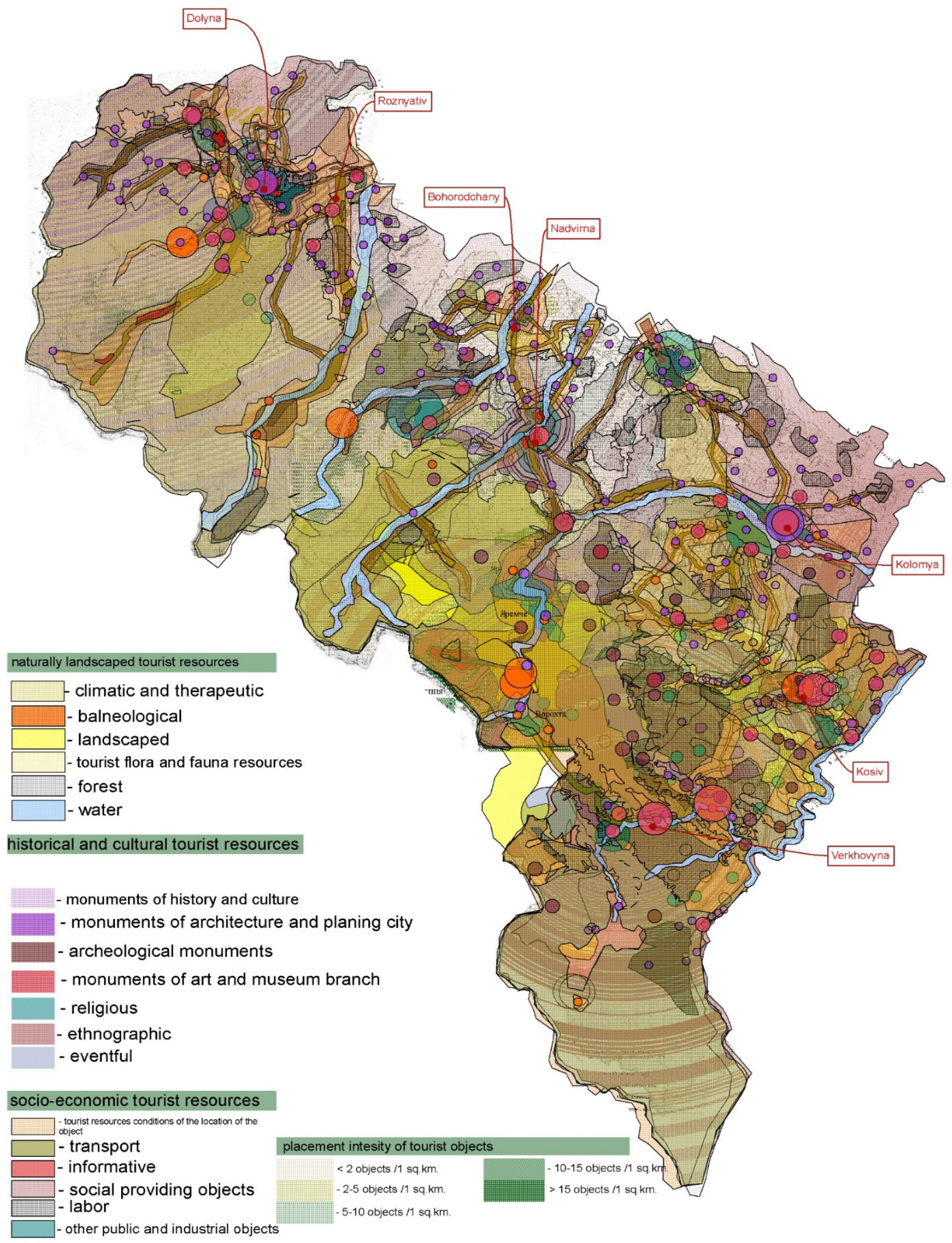

Figure 8 - The number of tourists in the administrative districts of the region in the summer and winter periods 2016-2017. The scheme was created during the field researches and author's information investigation.

In the Carpathian region, the intensity of the development of recreation is accompanied by the development of farmsteads and nutrition facilities formed around powerful recreational complexes. Indicators of intensity of accommodation of recreation facilities in administrative districts of Ivano-Frankivsk 
oblast were obtained from the statistical reporting of rayon departments of statistics and tourism departments in the region. During the research period of 2015-2017, natural surveys of 75\% of the research area were conducted, on the basis of which schemes of the development of tourism development in the mountainous regions of Ivano-Frankivsk oblast were created.

In Bogorodchany district intensive tourism development takes place in 2 zones:

- the outskirts of the village. Bogorodchan, which is a suburban area of the city of Ivano-Frankivsk. The following recreation facilities are located on this territory, such as hotels, tourist complexes, restaurants, aimed at short-term holiday accommodation for residents of the suburban area and Ivano-Frankivsk.

- Mountain zone within. Huta, Stara Guta, Porogy and Yablunka, where there are tourist complexes with a total capacity of 400 people. Within the territory of this territory are formed objects of rural tourism, systems of roadside cafes and parking lots. In this area of intensive tourism, the religious complex Maniavsky Skit functions as the center of recurrent tourism throughout the region (Figure 9). 


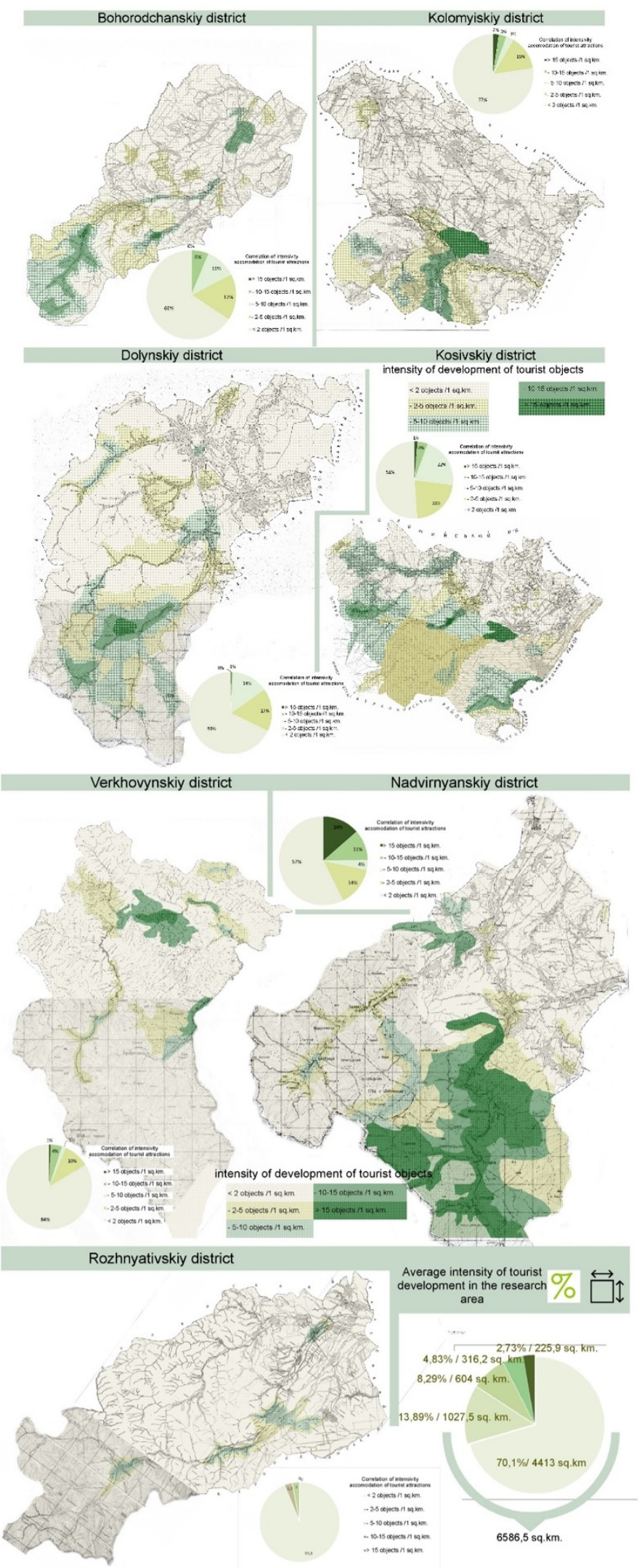

Figure 9 - The state of construction of tourist facilities in the mountainous regions of Ivano-Frankivsk region. The scheme was created during the field researches and author's information investigation. 
In the north-eastern part of the Bogorodchany district, which is part of the suburban area of IvanoFrankivsk $(30 \mathrm{~km})$, Tourism development is the least intensive, and objects located on this territory are located separately with weakly developed structural connections.

In Kolomyia district intensive tourism development takes place in Kolomyia and in the foothills of the Kolomyia district near the Kolomyia-Kosiv highway, where the objects of rural tourism are concentrated. Placement of Kolomyia at the intersection of main roads provided for its functioning as a tourist center of ethnographic and recreational tourism. The north-eastern part of the district has an agrarian profile, the recreation infrastructure on this territory remains at the initial stage of formation and is represented by separate recreation places near natural objects (forest bands, rivers, lakes).

In the Dolynskyi region, the zone of the highest intensity of tourism is located within the settlements Myslivka, Vyshkiv, Vygoda. On this site there are objects of rural tourism and ethnographic tourism.

The highest indicators of the intensity of the location of tourism objects can be traced on the territory of the city of Kosiv (numerous museums, mansions of prominent persons, small tourist objects) Tiudiv, Kuty, Velykyi Rozhen (historical component of cultural and religious layers) where hotels, restaurants, infrastructure of roadside motels and cafes are located, and in the natural environment (at a distance of $2 \mathrm{~km}$ from the highways) a network of rural tourism objects. Territory with Kosmach, one of the centers of ethnographic tourism.

The low intensity of the accommodation of tourism objects can be traced in Verhovinskyi district. Less than $1 \%$ of the territory with an intensity of more than 15 objects per 1 hectare are located within Kryvorivnia, Verhovyna and Dovgopillia. On this territory there are ethnographic, historical, historical and cultural museums, which became the basis for the development of rural tourism.

Nadvirna district has the highest intensity of accommodation of tourism objects, represented as powerful complexes (TC "Bukovel") and smaller objects of skiing tourism and rural tourism. This territory covers the area of settlements of Tatariv, Mykulychyn, Yaremcha, Vorokhta, Yablunytsia, Lazeshchyna. Rozhniativskyi district is the region with the lowest indicators of tourism development. The complex conditions of the relief and the poorly developed network of highways are the main causes of the current situation. Rural tourism objects located on the territory of Yasen, Slyvky, Perehinsk and focused on landscape tourism resources. These schemes show the existence of large areas on the territory of research with low development rates (by $70.1 \%$ of the territory, which is $4413 \mathrm{~km} 2$ the number of objects of the tourist destination is less than 5 per hectare). In analyzing the scheme of tourist development it is observed that at the highest level of tourist development of Nadvirna and Dolyna districts, the cities themselves are abstracted in the system of functioning of the region, as industrial cities with ecological problems inherent in the oil and gas industry (Figure 10).

The ways of overcoming the tendency of inefficient use of tourist resources in the region should be sought, as in the reform of the system of state control, management and development of recreation, as well as qualitative change in the architectural and planning organization and the formation of recreational infrastructure on the basis of modern types of recreation (Suprapti et al., 2018). 


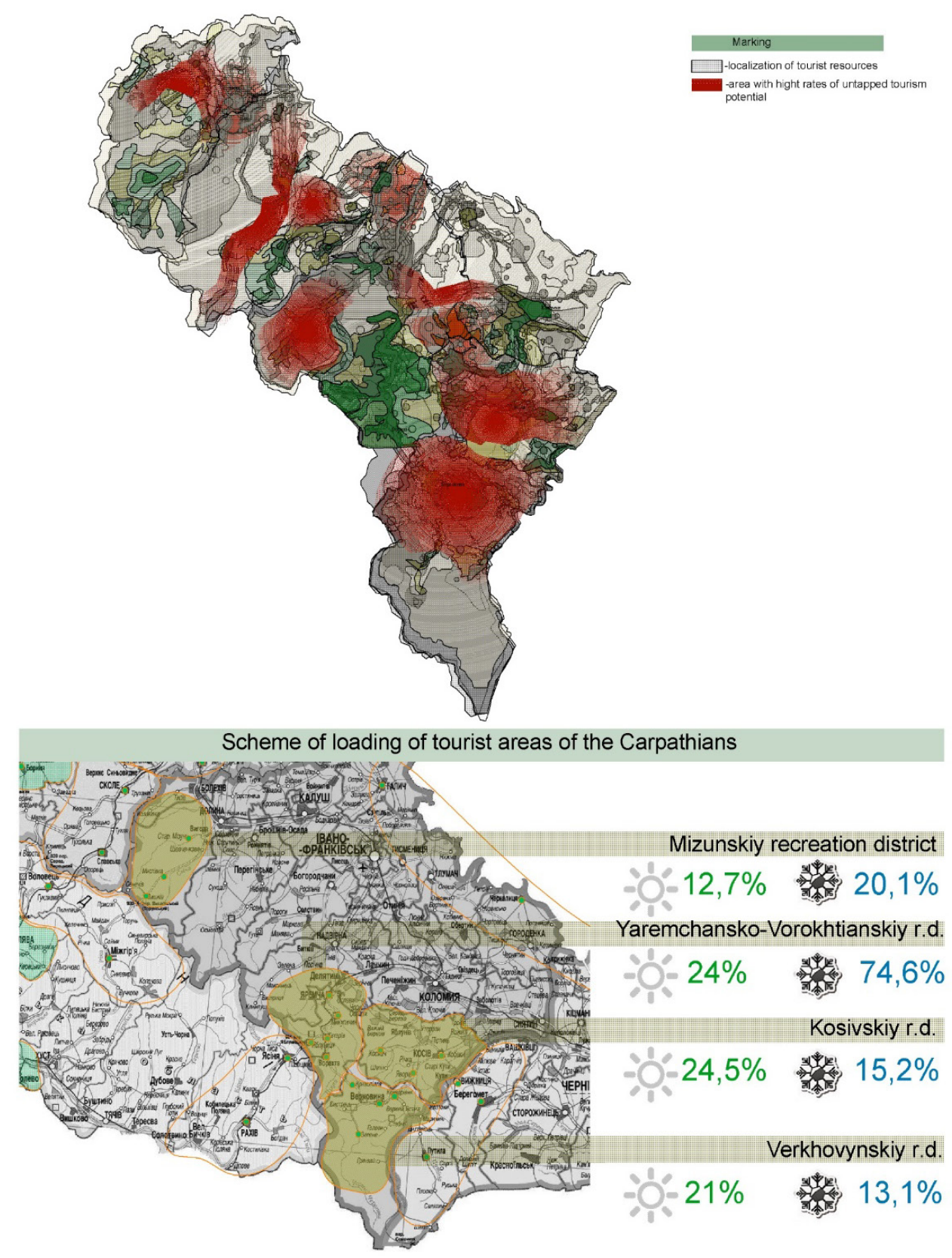

Figure 10 - Estimation of the potential of untapped tourist resources in the mountainous regions of IvanoFrankivsk region. The scheme was created during the field researches and author's information investigation.

\section{Principles of architectural organization and development of tourism on new touristic territories}

Influencing factors for the development and architectural organization of the objects of modern tourism creates the necessity of improvement existing principles of formation tourist environment.

The paper highlights 5 principles of architectural organization and development of tourism. They are: the principle of balanced use of tourism potential, the creation of new centers, increasing the type of multifunctionality, the preservation of historically-established architectural objects, the expansion of effective linkages between tourism facilities within separate areas and territories. 
The principle of balanced use of tourism potential involves the search for untapped tourism resources separately taken village or district and substantiation of ways of their inclusion in established tourism sector (Figure 11).

Balanced use of natural landscape tourism resources in a small area will lead to the improvement of the ecological status. It will increase the variability of travelers, will expand the attractiveness of the region (Milijic et al., 2017).

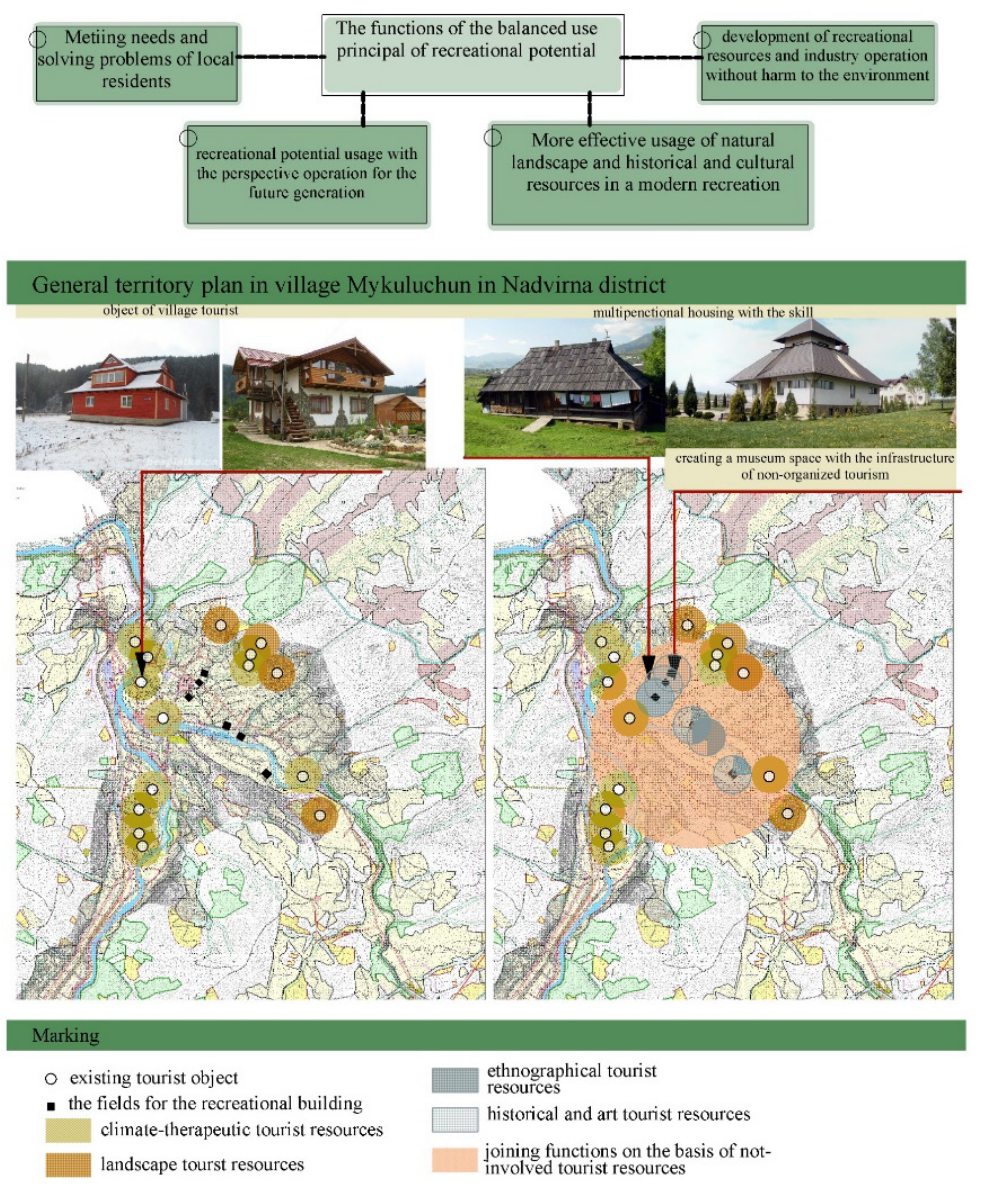

Figure 11 - The balanced use application of tourist potential. Scheme created by author.

An example of this principle application is the development of detailed plans of territories (DPT) in Mykulychyn, Nadvirnyansky district. The settlement has untapped recreational potential (forest, orographic, Floro-fauna, water, climatic and therapeutic, historical, artistic, architectural, archaeological, socio-economic, transport, environmental and labour recreational resources). There are 6 territories with total area of 15 hectares for the construction of tourist facilities. In this detailed site plan clearly regulates the following aspects that arise in design processes:

- adjusts the process of designing tourist facilities, infrastructure maintenance, utilities subject to planning, fire and sanitary restrictions;

- defines the parameters of future construction: number of floors, maximum height, etc.;

- substantiates the possibility of attracting additional areas as part of attractions;

- defines compulsory construction features of the service and makes proposals for their development (sequence of development). 
Because of globalization in all spheres of economy and information transparency the requirements for the formation and activities of tourism enterprises and their services has changed. The modern tourist is not limited to the stay in the territory of residence. The radius of coverage of a tourist staying in 1 place can be up to $50 \mathrm{~km}$. (The solution to this problem is possible through the application of the creation of new centers, which involves the search of opportunities to attract tourist and prospective settlements of a certain district in this area (Dringelis et al., 2015). There is a need to create a nodal system of placing tourist objects. Its benefits means the possibility of creating a common engineering infrastructure (Sewerage network, sewage treatment plants), construction of which is the most expensive part of the project, especially in mountainous area. Create base infrastructure of tourism should occur on the basis of attracting tourism facilities in the current structure of the recreational centers. The implementation of this principle is focused on rural, recollecting, ski tourism (Figure 12).

An example of application of this principle is the formation of tourist nodes within Verkhovyna district. As it is known, the formation of the tourist site involves the combination of several tourist destinations on the basis of common relations. On the territory of Verkhovynsky district formed the following tourist destinations with the intense growth of tourism destinations and available tourism potential. Within villages Kryvopillya - Verkhovyna - Kryvorivnya - Verkhniy Yasenov should create tourist hub of rural tourism, ethnographic and ski recreation. In this area there is untapped potential for all types of tourism sources. Travel site Ustari - Barvinkiv should be formed on the basis of the same villages (potential natural landscape tourism resources allows you to create extreme, ski, ethnographic recreation and rural tourism). Travel site Zamahora Yavirnyk - Green - Dzembronya is bordered by the Carpathian biosphere reserve and located natural attractions, such as Hoverla, PIP Ivan and Berbeneskul, lakes Maricheika and Nesamovyte. Intense tourist flows here are from April to October. To improve its sesasonal popularity should create extreme recreation-based organized expeditions in the winter season with an extensive network of stations, tourist shelters, signage, sanitary points. This type promotes active types of tourism and does not harm the ecosystem. The basis for the formation of the tourism node Yablunitsa - Dolgopola have formed ski resort in the sec. Yablunytsya. 


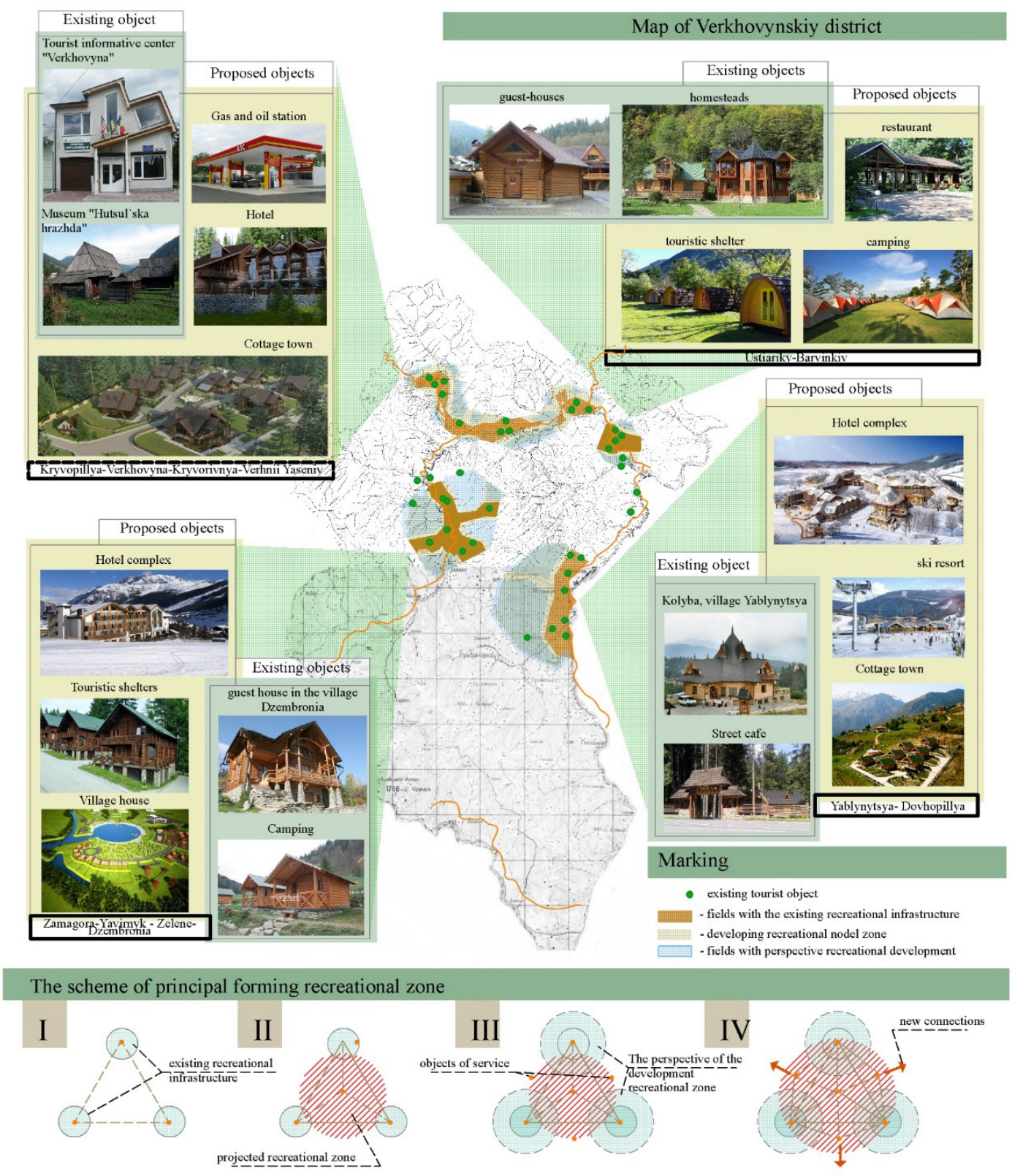

Figure 12 - Implementation principle scheme of the nodal integration of objects and the creation of new recreation centers. Scheme created by author.

The problem of low use of tourist potential is maintained in settlements of Kosiv, Verkhovyna, Rozhnyatovsky and Kolomyia regions. Increasing the efficiency of their functioning is possible through the application of the principle of increasing the type of multifunctionality, which involves the construction of modern tourism with all-season operation mode.

This principle involves changes in the functioning of existing tourism objects (within its specialization) due to an increase in the set of tourist services. Undoubtedly, the dynamics of the functioning of tourism objects will remain different during the year, but the total increase in capacity, will stabilize working conditions, increase revenues in local communities, and improve the use of recreational potential qualitatively (Grichting \& Zebich-Knos, 2017) (Figure 13). Demonstrate the application of this principle can be on the example of a cottage in the village Kobaky, Kosiv district. 


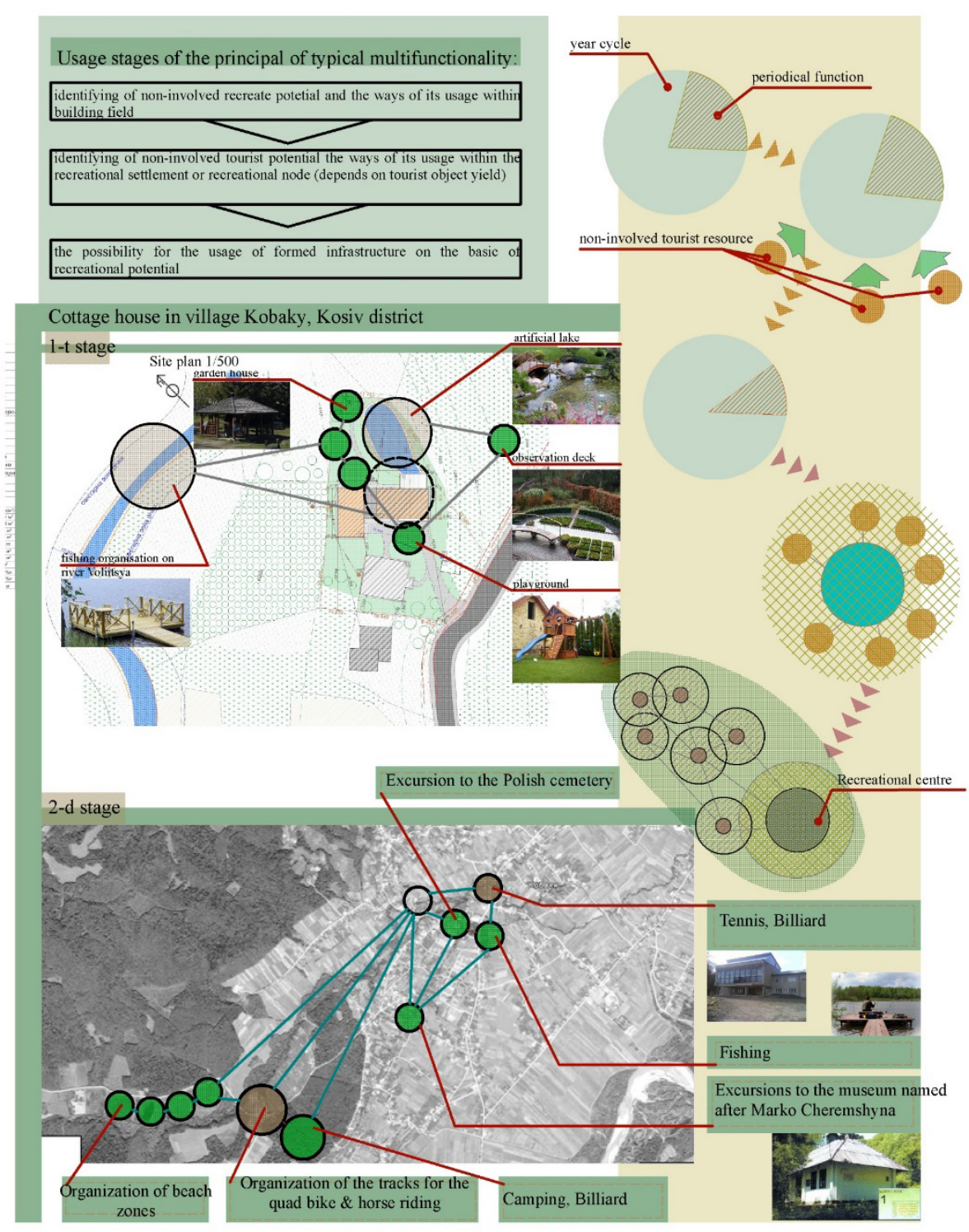

Figure 13 - The usage of the principal of increasing typical multifunctionality. Scheme created by author.

This cottage is of a family type, functioning in 2 quarters of the summer period, which is not profitable. The author proposed a program to enhance the universality of its functioning by providing additional services.

The analysis of untapped tourism potential at the site showed the presence of water, forest and transport tourism resources. Namely: along the river Volyitsa with a system of underground sources, which will allow owners of the estate to create a lake and trout in the territory; on the western side of the territory a natural relief is formed with a $9 \mathrm{~m}$ difference, which opens the panorama of the outskirts - an observation deck with a system of trails should be organized accordingly. In the architectural and planning features of the structure should include a terrace over the lake, and a system of gazebos that will allow you to do fishing.

At the level of the settlement there is a potential of the history and culture monuments (Marko Chermeshina museum). Here there are some touristic attractions: forest ( $1.5 \mathrm{~km}$ away from the site is a leafy forest with a camping town "Hat of the fisherman"), climatic and therapeutic (the system of parks in the settlement), infrastructure ( 2 motorways of regional significance at a distance of up to $5 \mathrm{~km}$.), 
religious (on the territory of the settlement there is a spiritual center "Zdvyzhyn"). Availability of tourist resources allows you to create a holiday program and provide hiking and cycling tours.

In the example shown, the advantageous location of the site with the proximity of the tourist hub in Kosiv ( $4 \mathrm{~km}$.) which provides the development of certain types of tourist resources (historical and cultural group of resources). Thus, the use of the existing tourist potential, on the basis of maximum attractiveness of tourism objects, takes place.

Carried out studies indicate insufficiency, and sometimes lack of awareness of both the local population and tourists about the placement of unique architectural, archeological and artistic monuments on the territory. There is also no organization of places of recreation and service near these objects. There is a need to apply the preservation of historically-established architectural objects. It involves the creation of additional museums, the transformation of existing architectural, historical, archeological and artistic objects into attractions and the development of ethnographic and archaeological tourism within the region, regions and individual inhabited points (Figure 14).

This is possible because of the inclusion of available samples of architectural, decorative, applied, historical, artistic, and archaeological heritage in the field of recreation. The application of this principle to objects of architectural and historical and artistic heritage has the following stages:

- formation of accounting objects of historical and artistic heritage and their location in the region;

- analysis of received information and definition of centers of tourism development;

- preservation, modernization and renovation of architectural and archaeological heritage with the organization of the entire site of the site;

- functioning of samples of historical and artistic heritage on the principles of tourist orientation: organization of additional places of rest and service near objects of historical and cultural heritage;

- definition of the formed tourist connections, on the basis of which additional objects of ethnographic and archaeological tourism, additional tourist routes, etc. should be formed. 


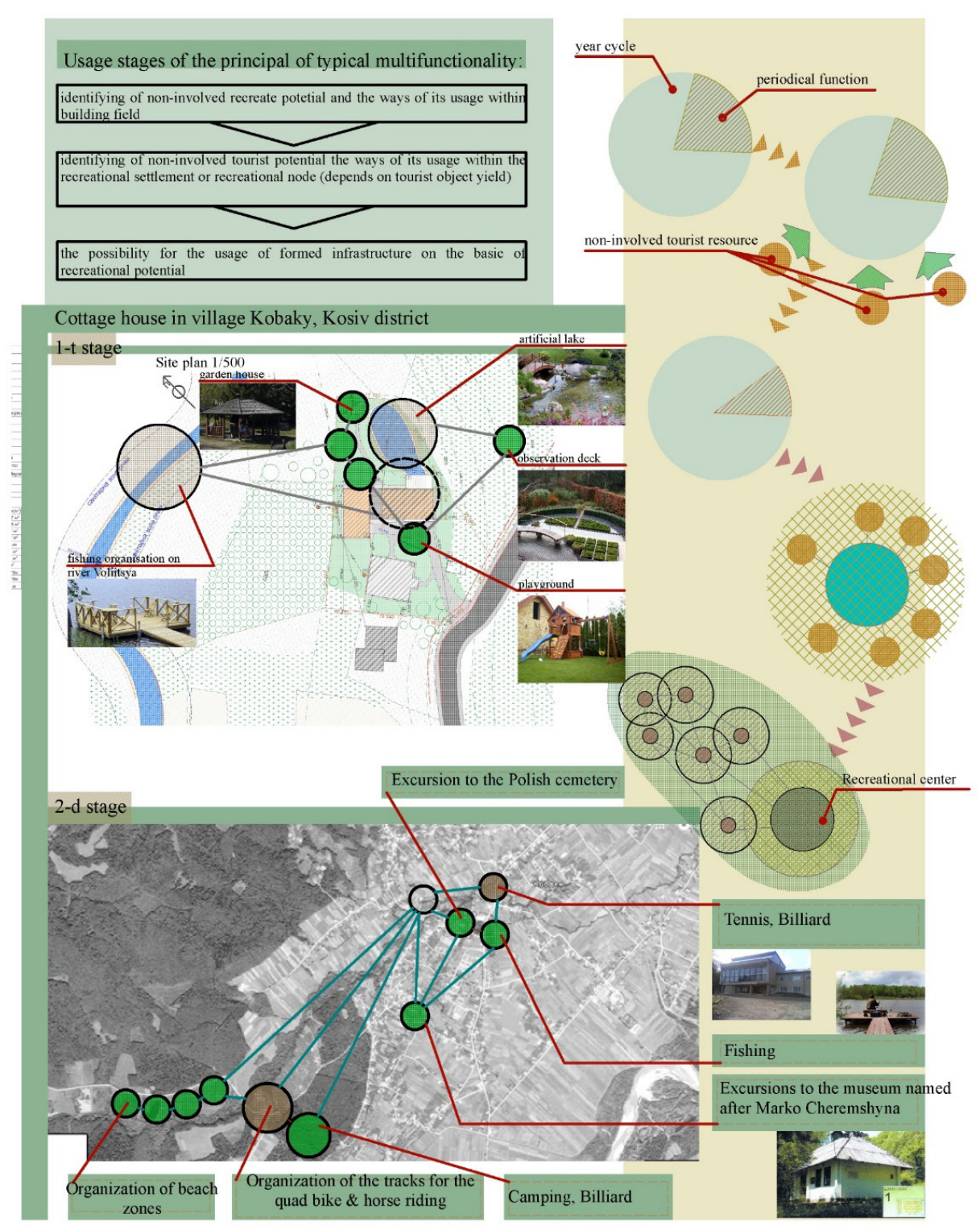

Figure 14 - The usage of museification of historically formed objects and territories for the ethnographical \& archeological tourism. Scheme created by author.

On Kosiv territory of the historical and cultural center was formed an ethnographic complex "The estate of St. Nicholas", as an example of ethnographic tourism. This object is a children-oriented tourist complex, the purpose of which is to popularize the historical and artistic heritage, increase spirituality of youth, as well as organization of tourist tours for children and their parents. At present, the first stage of the construction of this complex is realized. However, an increase in annual recreational flows indicates the potential for expansion of the complex functions.

Studies conducted in the region indicate the unsystematic functioning of tourism objects. To solve these problems, the expansion of effective linkages between tourism facilities within separate areas and territories, which is aimed at increasing the efficiency of recreation in settlements and the administrative district through the creation of tourist routes, which include different types of recreation, as well as cooperation between architectural objects, with different functions (accommodation, meals, rest and management) (Figure 15). 


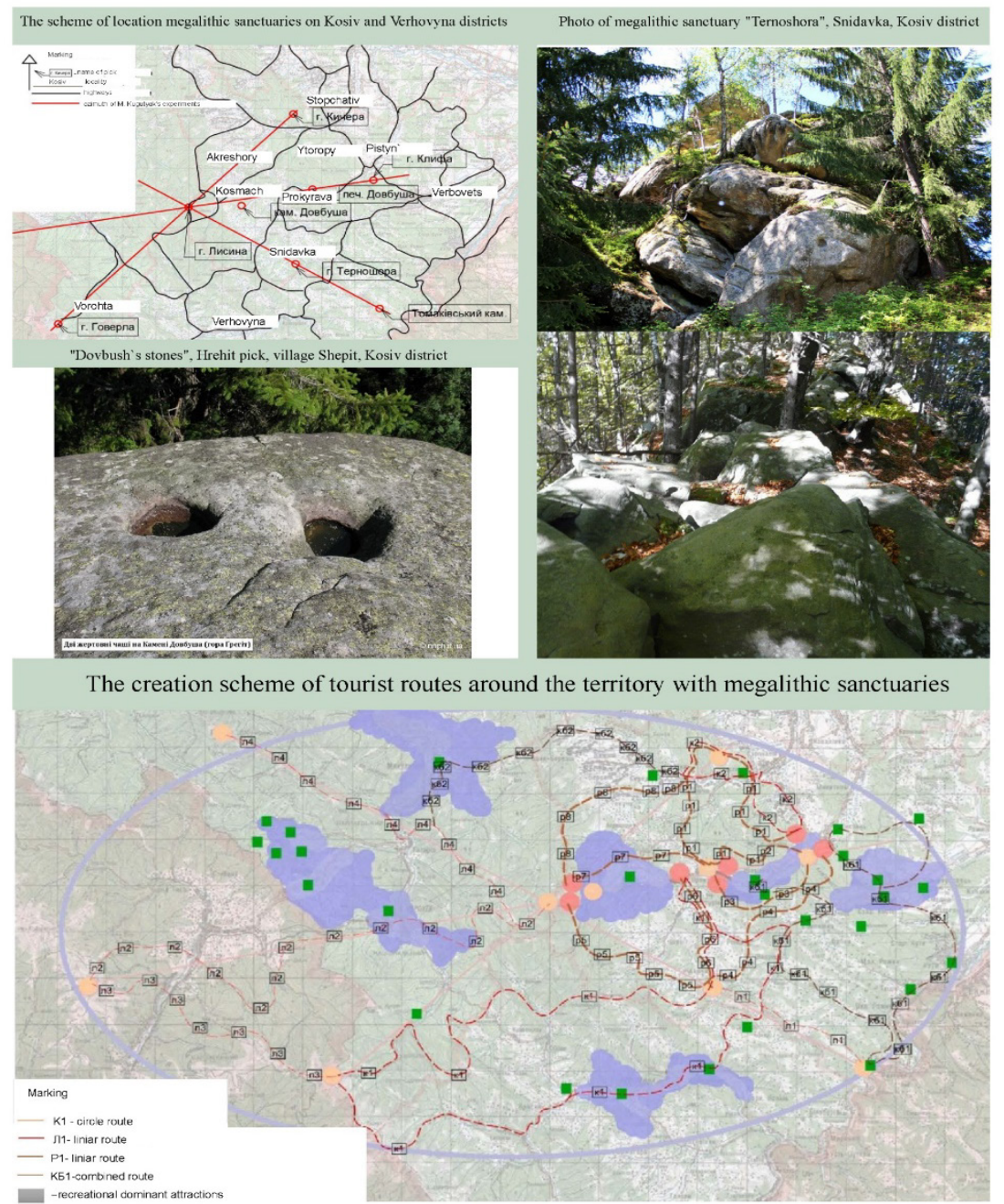

Figure 15 - Application of the principle of expanding effective ties between tourist objects. Scheme created by author.

In modern conditions, mobility of tourism is increasing. The bulk of tourists prepared for "mobile accommodation" are young people under the age of 35. Accordingly, there is a need to create additional places for short-term rest (campsites, campsites, tourist shelters), a developed network of tourist routes (differentiated by the age structure of tourists, the category of complexity of passage, typology). Na example of the application of this principle is the development of archaeological tourism in the area of the deployment of megalithic sanctuaries. Researches indicate the untapped potential of archaeological tourism resources, represented by a group of "megalithic sanctuaries" on the territory of Kosiv and Verkhovyna districts.

The criteria for their choice are justified on the basis of urban planning norms:

- distance from transport nodes of the design area is $1.5 \mathrm{~km}$;

- conditional boundaries of the sanitary zone of settlements - $2.5 \mathrm{~km}$ to residential development (this distance is taken as a prospective development of the settlement for 20 years);

- distance from megalithic sanctuaries to the design area - from 0.5-2.5 km (for the creation of children's and cognitive routes of the thematic direction).

According to the established criteria, the territory of the accommodation of tourist objects and the formation of tourist routes are substantiated. 
The proposed principles are aimed at improving the tourist space and improving the architectural and landscape characteristics of the studied areas.

\section{Conclusions}

By comparing the schemes of the location of tourist resources and the intensity of tourism development, the effectiveness of the use of tourism resources is determined. In particular, it has been established that Nadvirna and Dolyna districts have the highest level of tourist development.

There is a potential for the development of ski tourism, on the basis of the developed infrastructure, and extreme rest the potential of the development of historical and artistic tourism resources of the villages of Kosiv, Verkhovyna and Kolomyia districts, as well as existing museums of decorative and applied arts, may become the basis for the development of the historical and cultural type of tourism in this territory. The basis for the development of recurrent tourism is the revival of religious centers. There are 5 centers in the studied territory: in the village. Maniava of Bogorodchany district, Otyniia of Kolomyia district, Putyla of Verhovinskyi district, Kolomyia, Dzembronia of the Verhovynskyi district. In Kolomyia district there is a potential of socio-economic tourism resources (network of highways, placement), which will ensure the development of recreational recreation within the range. The analysis of the intensity of tourist development shows the low development of tourism in foothill settlements. Most clearly this problem can be traced on the example of Kolomyia district. Resource potential of tourism infrastructure is oriented on natural and landscape conditions. The lack of orographic and forest resources and the 50-year state policy on the development of the agrarian sector have resulted in a low level of development of recreational facilities in Kolomyia and Kosiv districts, where there is the greatest potential for functioning of rural tourism.

The author thanks the local residents and owners of tourist facilities in the area under study, as well as the chief architects of the administrative districts where the research for cooperation was conducted.

\section{References}

Decerkva. (2019). Wooden churches of Western Ukraine. Retrieved in 2019, March 25, from http://decerkva.org.ua/fra/bohorodchanskiy.html

Dolyna. Municipal. (2011). Rishennya Doly`ns 'koyi rajonnoyi rady`shostogo skly kannya. Pro programu rozvy 'tku tury`zmu v Doly’ns 'komu rajoni na 2012-2015 roky` (desyata sesiya) [About the program of development of tourism in Dolynsky district for 2012-2015, 197-10/2011 decision Dolynsky district council of the sixth convocation (tenth session)]. Dolyna: Dolyna District Council.

Dovzhuk, B. (2005). Aktual’ne regional’ne doslidzhennya trudovoyi migraciyi [An urgent regional study of labor migration]. Ukrainian Aspect of Labor, 3, 37-39.

Dringelis, L., Ramanauskas, E., Povilaitienè, I., \& Mačiukènaitė, J. (2015). Exploration and respectation of the spatial structure of cities, towns, townships and villages as a significant formant of their identity. Journal of Architecture and Urbanism, 39(1), 79-100. http://dx.doi.org/10.3846/20297955.2015.1028509.

Gabrel, M. (2004). Prostorova organizaciya mistobudivny`x sy`stem (pp. 350-355). Kiev: Spatial Organization of Urban Development Systems.

Google Maps. (2019). Retrieved in 2019, March 25, from https://www.google.com/maps

Grichting, A., \& Zebich-Knos, M. (Eds.) (2017). The social ecology of border landscapes. London: Anthem Press.

IGotoWorld.com. (2019a). Holiday options in the Carpathians in summer. Retrieved in 2019, March 25, from https://ua.igotoworld.com/ua/poi_catalog/388948-543-temples-kolomyia.htm 
IGotoWorld.com. (2019b). Національний музей народного мистецтва Гуцульщини та Покуття, Коломия [Hutsul and Pokuttya National Museum of Folk Art, Kolomyia]. Retrieved in 2019, March 25,

from https://ua.igotoworld.com/ua/poi_object/65990_national-museum-of-hutsulshchyna-and-pokuttya-folkart.htm

Ionela, G., Constantin, B. M., \& Dogaru, L. (2015). Advantages and limits for tourism development in rural area (Case Study Ampoi and Mureş Valleys). Procedia Economics and Finance, 32, 1050-1059.

http://dx.doi.org/10.1016/S2212-5671(15)01567-1.

Ky'fyak, V. F. (2003). Organizaciya tury'sty'chnoyi diyal'nosti v Ukrayini [Organization of tourism activity in Ukraine] (pp. 23-42). Chernivtsi: Books.

Maruya, K., Yamashita, S., \& Uchiyama, T. (2015). Community spaces in the minds of traditional craftsmen in a pottery village in Japan. Frontiers of Architectural Research, 4(4), 253-262.

http://dx.doi.org/10.1016/j.foar.2015.05.002.

Milijic, S., Micic, S., \& Maksin, M. (2017). Retrospective of and prospects for the development and strategic planning of tourism in the mountain regions of Serbia. Spatium (Belgrade), (37), 42-48.

http://dx.doi.org/10.2298/SPAT1737042M.

Panchenko, T. F. (2000). Aktual'ni aspekty`organizaciyi sil’s 'kogo tury`zmu (oglyad problem ta deyaki rekomendaciyi). [Current aspects of the organization of rural tourism (review of problems and some recommendations)] (Vol. 3, Tourist-lore studies, pp. 58-65). Kyiv: PE Ilchenko.

Pitiulych, M. M. (2015). Rehuliuvannia rozvytku hirskykh terytorii v umovakh modernizatsii ekonomiky Ukrainy. (Doct. Diss.). Dolishniy Institute of Regional Research of NAS of Ukraine, Lviv.

Pozniak, O. V. (2016). Otsiniuvannia naslidkiv zovnishnoi trudovoi mihratsii v Ukraini. Demography and Social Economy, 2(27), 174-175. http://dx.doi.org/10.15407/dse2016.02.169.

Richins, H. (2016). Experience provision in mountain tourism: overview, contextual development and emphasis. In H. Richins, \& J. Hull (Eds.), Mountain tourism: experiences, communities, environments and sustainable futures (pp. 13-24.). UK: CABI. http://dx.doi.org/10.1079/9781780644608.0013.

Schmidt, J. T., Werne, C., \& Richins, H. (2016). Mountain tourism in germany: challenges and opportunities in addressing sustainability of garmisch-partenkirchen. In H. Richins \& J. Hull (Eds.), Mountain tourism: experiences, communities, environments and sustainable futures (pp. 255-280). UK: CABI.

http://dx.doi.org/10.1079/9781780644608.0255.

Smadych, I. P. (2013). Novi vy'dy' rekreaciyi na osnovi megality'chny'x svyaty'ly'shh Pry'karpattya [New types of recreation on the basis of megalithic sanctuaries of the Precarpathians] (Vol. 49, Urban Planning and Territorial Planning, pp. 493-501). Kiev: KNUBA.

Smadych, I. P. (2015). Zastosuvannya metodu poshuku radial'nogo oseredku v konteksti novy'x vy'div rekreaciyi na Pry'karpatti [Application of the radial cell search method in the context of new types of recreation in the Carpathian region] (Vol. 38, Modern Problems of Architecture and Urban Development, pp. 283-292). Kiev: KNUBA.

State Statistics Committee of Ukraine. (2011). Metodologichni polozhennya zi staty`sty`ky` tury`zmu/Derzhavny`j komitet staty 'sty 'ky' Ukrayiny [Methodological provisions on tourism statistics] (Vol. 372, pp. 18). Kiev: State Statistics Committee of Ukraine.

State Statistics Service of Ukraine. (2018). Selective data from the State Statistics Service of Ukraine from IvanoFrankivsk region. Ukraine: Statistics Department in the Ivano-Frankivsk region.

Steinberg, F. (1996). Conservation and rehabilitation of urban heritage in developing countries. Habitat International, 20(3), 463-475. http://dx.doi.org/10.1016/0197-3975(96)00012-4.

Suprapti, A., Kim, S., Pandelaki, E. E., \& Firmandhani, S. W. (2018). A spatial dialogue of heritage village between kauman in semarang and seochon in seoul toward preservation development. Journal of Architecture and Urbanism, 42(1), 16-23. http://dx.doi.org/10.3846/jau.2018.1478. 
Wang, J., \& Wang, X. (2015). Transition of Chinese urban-rural planning at the new-type urbanization stage. Frontiers of Architectural Research, 4(4), 341-343. http://dx.doi.org/10.1016/j.foar.2015.09.001.

Wikipedia. (2017). Vicki loves sights. Ivano-Frankivsk region from. Retrieved in 2019, March 25, from https://uk.wikipedia.org/wiki/\%D0\%92\%D1\%96\%D0\%BA\%D1\%96\%D0\%BF\%D0\%B5\%D0\%B4\%D1\%96\%D1 \%8F:\%D0\%92\%D1\%96\%D0\%BA\%D1\%96_\%D0\%BB\%D1\%8E\%D0\%B1\%D0\%B8\%D1\%82\%D1\%8C_\%D0\%BF \%D0\%B0\%D0\%BC\%27\%D1\%8F\%D1\%82\%D0\%BA\%D0\%B8/\%D0\%86\%D0\%B2\%D0\%B0\%D0\%BD\%D0\%BE\%D0\%A4\%D1\%80\%D0\%B0\%D0\%BD\%D0\%BA\%D1\%96\%D0\%B2\%D1\%81\%D1\%8C\%D0\%BA\%D0\%B0_\%D0 \%BE\%D0\%B1\%D0\%BB\%D0\%B0\%D1\%81\%D1\%82\%D1\%8C

Editors: Janaina Camile Pasqual Lofhagen and Christopher Hawkins.

Received: Mar. 25, 2019

Approved: Apr. 26, 2019 